\title{
高エネルギー加速器固体ターゲットの流路設計と熱伝達実験 \\ Design of flow route and a heat transfer experiment of solid target for high energy accelerator
}

生駒 究（神戸大院）

正 竹中 信幸（神戸大工）
奥本 元（神戸大工）

Kiwamu Ikoma, Gen Okumoto,

Nobuyuki Takenaka,

Dept. of Mech. Engng., Kobe Univ., Rokkodai-cho, Nada, Kobe 657-8501

\begin{abstract}
A high energy proton beam is irradiated to heavy metal called a target to produce neutrons. It was necessary to consider a special cooling procedure using high speed water flow in order to cool extremely high heat deposition in target. Experimental studies two kinds of targets plate and rod types were conducted for determining the most suitable shape of distributor, measuring pressure loss and a distribution of the flow velocity. From the experiment and simulation result, the optimum shape and the validity of the target were shown.
\end{abstract}

Keyword: accelerator, solid target, thermal hydraulic design, rod bundle,

\section{1. 楮害}

高エネルギー加速器固体ターグットでは、陽子線をターグ ットと呼ばれる重金属に照射し、核破砕を起こして高速中性 子を発生させることを目的としている。この際、ターダット では最大 $1 \mathrm{GW} / \mathrm{m}^{3}$ 以上の高密度の熱が発生するため、特別な 冷却方法を検討する必要がある。そこで本研究では、固体タ 一グットを秒速十数メートルの高速水流で泠却する際の問 題点を実験的に吟味するために、現在高エネルギー加速器機 構で検討されているターゲットシステムとほほ同じ大きさ の実鈎装固を作り、ターダットの設計、製作を行い、流動分 配実験、熱伝達実験を行った。

\section{2. 実确装唯}

Fig. 1 に実験装置の概略図を示す。作動流体には脱気した 水を用いた。ポンプ(かから送り出された水は、バルブ V1、V 2 で流量を調整され流量計(2)を通り試験部に流入し、試験部 をから冷却器(5)を経て再びポンプにもどる。

ターダットには平板型とロッド型の 2 種類が考えられ、平 板型ターダットについては平行型と直行型の二通りの試験 部を検討した。冷却水の主流の流れに対して、ターゲットデ イスクが平行なものを平行型試験部、直行しているものを直 行型試験部とする。本研究では、平行型と直行型の 2 種類の 試験部に対して実験を行い、流速分布、流線及び圧力損失を 誳べた。

\section{3.平板型ターゲット}

試験部は内部の流動を可視化するためにアクリル樹脂製 とした。試験部は本体とディストリビュータ部に分離するこ とができる。本体は、核破砕中性子源ターゲットを模擬した 厚さ $5 \mathrm{~mm}$ 、幅 $60 \mathrm{~mm}$ 、長さ $227 \mathrm{~mm}$ のディスクを $1.5 \mathrm{~mm}$ 間 隔で 19 枚並列に設置し、その隙間に水を流し、本ポンプ仕 様の最大流量では約 $20 \mathrm{~m} / \mathrm{s}$ の流速が得られる。ディストリビ ュータ部は、内部にアクリル製の透明ブロックを設置するこ とによって、種々の入口形状をつくることができる。

平行型試験部については流量分配実験とシミュレーショ ンからディストリビュータ部の最適形状を設計して、実証試 験を行い最適形状であることを確認した。その結果を Fig2. に示す。

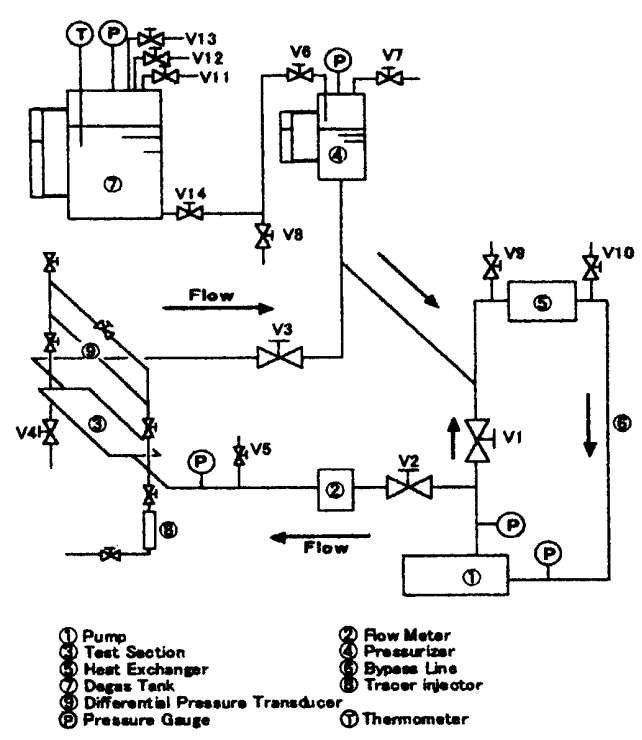

Fig.1 Experimental Apparatus

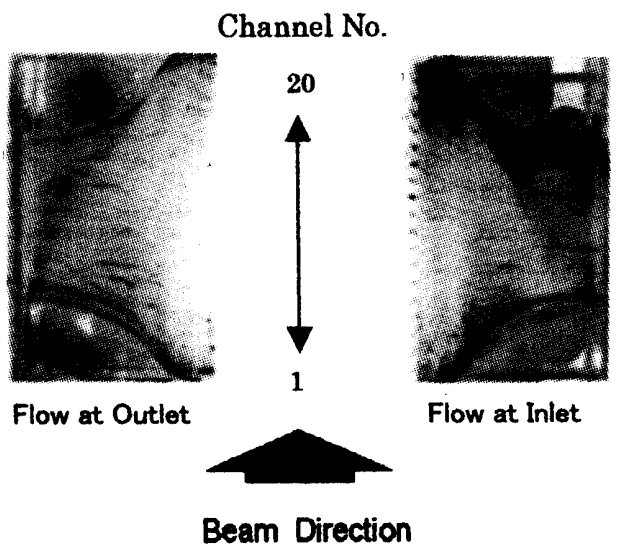

Fig.2 The most suitable distributor 


\section{4.ロッド型ターゲット}

ロッドはタングステンにシースの材貿としてタンタルと ジルカロイを使用した 2 種類が考えられている。ロッド型タ 一ゲットの特性を調べるために、まず幾何的に評価し 3 次元 熱応力を調べる。それからロッドの直径を決定しターダット としての平均密度を計算し有効性を考察する。

\section{ロッドの直径}

実際にロッドの直径を決める。ここでロッドの発熱により 冷却水が沸䅈すれば均一な水の流れが阻害され熱伝達率が 低下するチャンネルが生じる可能性がでて、危険であること が予想される。冷却水は 10 気圧程度に加圧することを想定 しており、飽和温度は $180^{\circ}$ Cであるので、照射時のロッド の表面温度の上限を $120^{\circ} \mathrm{C}$ とて直径 D[m]を決定し、そ の場合のターグットの性能評価を行う。

図中の $\mathrm{W}_{\mathrm{p}}$ はビームのパワー、 $\mathrm{d}_{\mathrm{w}}$ はロッド閒の距離である。

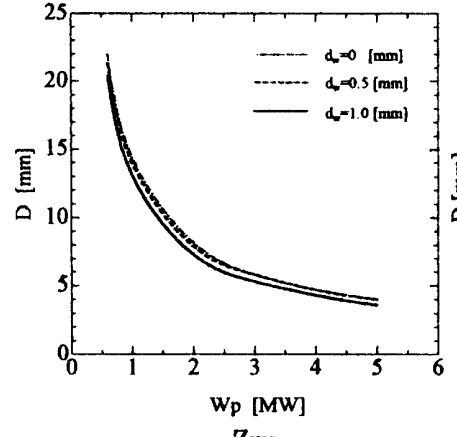

Zry

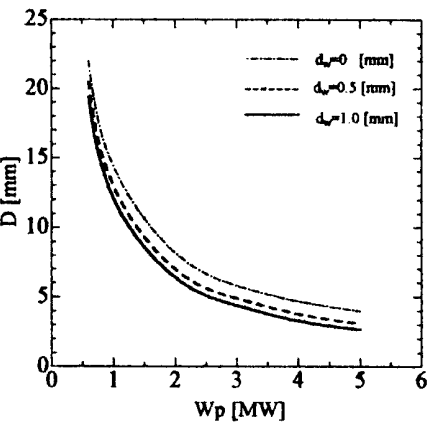

$\mathrm{Ta}$
Fig.3 Diameter of rod

\section{ロッドの平均密度}

中性子の発生効率はターゲットの密度にほぼ比例するこ とが知られている。ロッドの直径から平均密度を求める。平 均密度はロッドの断面を考えたとき、面㮴の割合とその面積 を占める材質の密度から決まる。ここで陽子線を照射しても 中性子を出さない水の密度は 0 と考える。平均密度 $\rho$ avをグ ラフ化しそれを Fig. 4 に示し水銀と比較する。

ビームのパワーが 1 [MW]の時はZ Zry、Ta でシースしたロ ッドとも $\mathrm{d}_{\mathrm{w}}$ に関係なく水銀より平均密度が大きくターダッ トとしては魅力的である。Zry は原子炬で一般的に使用され ており、材料として信頼性が高い。ビームのパワーが 1.5 [MW]までは Z ry でシースされたロッドは水銀より平均密度 が大きいことがわかった。
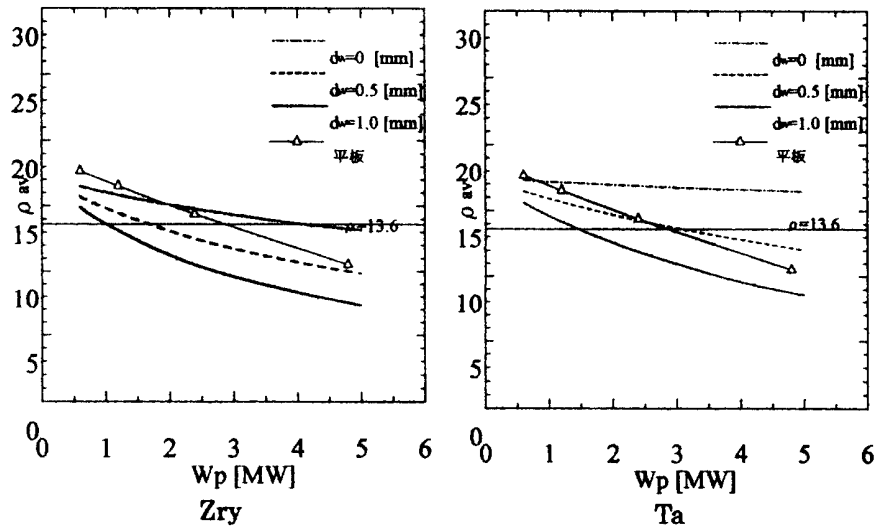

Fig.4 Average density of rod

\section{ロッド型ターダットの流動害蹈}

Fig.6のように試绉部全体の流路の形状は直交型を用いた。 試験部本体にはバッフル板にロッドを取り付けたロッド型試 部部を装着した。ロッドの素材には水と屈折率がほぼ等しい フロロカーボンを用いて実験時になるべく内部まで襩察しや すいようにした。Fig.7で示される流速分布はトレーサー法と 高速ビデオカメラによって計測した。

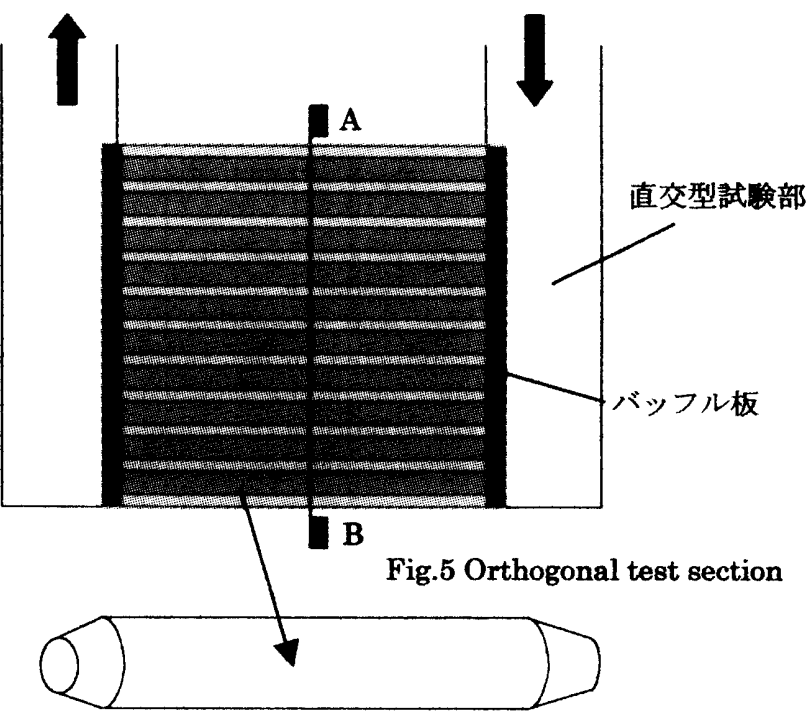

Fig.6 Rod
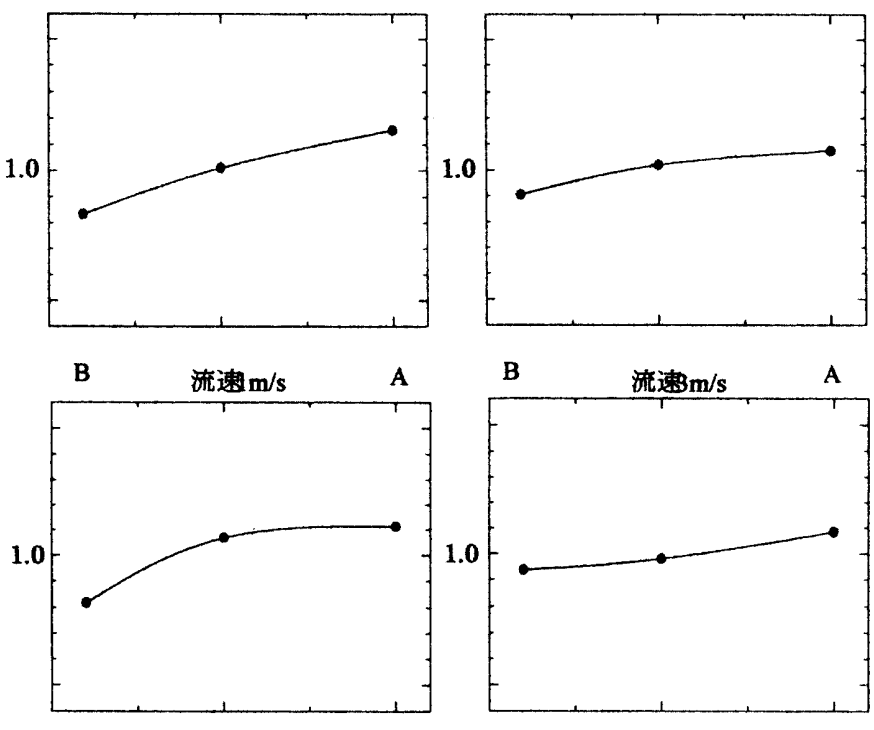
流速 $\mathrm{m} / \mathrm{s}$

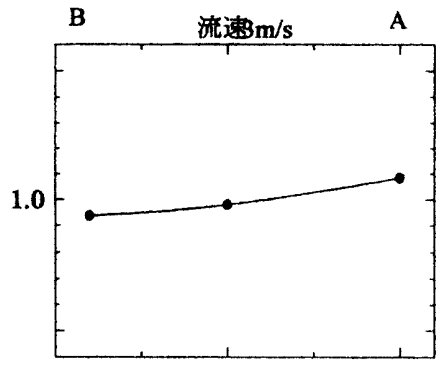

流速 $0 \mathrm{~m} / \mathrm{s}$

A

\section{5. 結㻅}

1）平板型ターダットはシミュレーションと流動実験から ディストリビュータ部の最適形状を決定することがで きた。

2）ロッド型ターグットについては各流路における流速は $\pm 10 \%$ 以内でほぼ均一に流れており実祭の使用に関 して問題ないことが確認できた。

ロッド型ターゲットではロッド間の距離を一定に保つ ためにワイヤを巻いており熱伝達率の向上が期待できる。 今後は試験部を発熱させて熱伝達実検を行う予定である。 